\title{
"ABRAÇOS DE MONO": ELOS PERDIDOS E ENCONTROS INTERSUBJETIVOS EM ETNOGRAFIA COM PRIMATÓLOGOS NO BRASIL
}

Guilherme José da Silva e Sá

\begin{abstract}
Apesar dos milhões de anos de evolução diferenciada que separam os homens de seus parentes peludos [...] nosso imaginário continua a latejar noite adentro em torno da utopia muriqui. A busca de arquétipos que nos expliquem e nos reconfortem é um vício da humanidade. Uma bengala existencial. Podem inspirar fabulações pueris, nas quais o reino animal confunde-se com um éden edulcorado e ingênuo. Podem resvalar para um determinismo obscurantista, que menospreza o papel da sociedade e da cultura no comportamento do homem. Mas talvez o efeito mais importante dessa busca seja precisamente esse, instigar reflexões não simplistas sobre a natureza híbrida do fato humano, enredado inexoravelmente - numa teia de opções e imposições (Globo Rural, ano 13, n.149, março 1998).
\end{abstract}

\section{Abraços de mono}

Sentada à mesa da cozinha, após ter terminado todo o serviço de limpeza da casa, D. Leda estava entretida na conversa com os funcionários e por alguns minutos suas palavras escaparam entre os lábios traindo aquela timidez de quem não gosta de ser fotografada. Ela falava do tempo de sua juventude, em que os habitantes locais temiam atravessar a mata pela estradinha de terra que cruzava a fazenda. O medo era fomentado pela existência de fantasmas (ou espíritos) de monos. ${ }^{1}$ Naquela época, os monos eram temidos como animais selvagens que, acreditava-se, atacavam os transeuntes à beira da estrada. As ameaças vinham por meio dos gritos, dos arremessos de galhos e dos abraços que transformavam animais medindo até $1,20 \mathrm{~m}$ em seres ainda maiores.

Ter vergonha de tamanho sentimento de medo só faria sentido a partir da chegada de outros seres à fazenda em meados dos anos 1970: os biólogos. 
Desde então, a percepção dos moradores a respeito dos monos como animais agressivos foi radicalmente alterada. O receio de um encontro casual deu lugar a um sentimento de curiosidade pelos macacos e também pelos sujeitos que vinham de tão longe para vê-los. Os abraços grupais, outrora tão ameaçadores, haviam sido ressignificados em uma nova expressão: "o abraço de mono".

Mais próximo da antiga descrição dos moradores locais, os pesquisadores inicialmente detiveram-se no entendimento dos "abraços de mono" como uma reação à sua própria presença na mata, ou seja, como um comportamento de intimidação. A atitude agressiva com os humanos explicava-se pelo histórico de anos de caça que teria consolidado na memória dos muriquis sua imagem como um perigo em potencial. Esta explicação aplicava-se perfeitamente ao contexto de ameaça de extinção da espécie. ${ }^{2}$

Este evento - o "abraço de mono" — associado à ideia de comportamento de intimidação pode ser ilustrado do seguinte modo: um macaco dependurado de cabeça para baixo, suspenso apenas pela cauda, coligado a diversos outros indivíduos. Isto o faz parecer maior, e o clima apavorante intensifica-se pela emissão de ruídos intensos. Subitamente, após contrair os músculos da cauda para se elevar, o aglomerado de ponta-cabeça parece lançar-se contra seu agressor, esticando braços e caudas. Hoje em dia, este evento é considerado raro entre os muriquis da Reserva ${ }^{3}$ - exceto quando o que está em disputa é um território ou uma fonte alimentar — pois, dizem os biólogos, ao contrário da motivação inicial para este comportamento, atualmente os macacos não possuem agressores iminentes. Entretanto, o gesto de abraçar ainda é algo facilmente verificável entre os muriquis da Reserva. Este teve sua leitura, seu significado deslocado. A esta atitude coincide uma primeira mudança na forma de olhar para os macacos. Se anteriormente suas performances eram consideradas ameaçadoras, agora abraços e apertos de mão tornaram-se mecanismos de conservação da unidade do grupo com os quais dois ou vários indivíduos, machos e/ou fêmeas, se procuram para estabelecer contato físico. Podendo ocorrer em diversos contextos, que vão desde o deslocamento para locais de descanso ou alimentação, durante uma inspeção sexual, até a expulsão de algum intruso, os abraços de mono estão genericamente relacionados a algum tipo de manifestação de afetividade ou emoção.

As emoções envolvidas na ótica atual do abraço situam-se em categorias distintas daquelas reações iniciais mediante o contato com humanos. A primeira explicação é extraída da prática, calcada no histórico de contato conflituoso entre humanos e animais. Esta foi suplantada por uma concepção fundamentada na observação intimista e duradoura da vida muriqui. É neste 
momento que o ser humano (primatólogo) abdica de sua participação ativa ("quando era caçador", "quando era morador") na relação predisposta para isolar o termo primata como foco gerador de suas próprias idiossincrasias. Os abraços de mono deixam de ser simples gestos reativos e elevam-se à categoria de padrão comportamental da espécie. Junto com esta mudança na qualidade do abraço, parece ter seguido uma alteração na forma de ver o próprio mono-carvoeiro.

Os estudos dos primatólogos não apenas ressignificaram os abraços como reavaliaram a imagem do muriqui. Indícios de uma sociedade pacífica, não beligerante e não hierarquizada formaram a opinião de diversos meios de divulgação científica e serviram de bandeira conservacionista e acadêmica em prol da especificidade do mono. Falarei disso mais adiante. Por enquanto, fico com o exemplo seguinte, a fim de demonstrar como a imagem do muriqui passa a ser representada:

O Brasileiro Cordial: a sociedade muriqui é um patrimônio inigualável. Nela a violência inexiste e uma das instituições mais importantes para manter a coesão grupal é o abraço. O muriqui é o verdadeiro brasileiro cordial. [...] Nascida a cria [...] mamãe muriqui sai abraçando cada membro do grupo para apresentar o filhote. Não existe violência entre eles. Divergências são resolvidas com vocalizações semelhantes a relincho de potro novo. Não há hierarquia de dominação. Todos são iguais. As fêmeas copulam livremente. Ninguém é dono de ninguém. O contato físico é sempre amistoso ou sexual, nunca agressivo. O símbolo mais fiel desta utopia animal são os abraços grupais que formam verdadeiros cachos de corpos entrelaçados no alto das árvores. Enquanto há comida e espaço suficientes, os muriquis não conhecem agressividade, estresse ou agonia [...] (Globo Rural, ano 13, n.149, março 1998).

A despeito das referências ao tipo criado por Sérgio Buarque de Holanda - licença poética dada a um jornalista inspirado - a ideia é a de que o abraço de mono passa a ser o símbolo de uma espécie singular de primatas que vive sob uma estrutura social igualitária e não agressiva. Um gesto tão celebrado por todos os envolvidos na pesquisa e preservação dos muriquis que se tornou um cumprimento entre os próprios seres humanos. ${ }^{4}$

\section{Muriquis: um todo à parte}

As denominações muriqui e mono-carvoeiro $($ mono = macaco em espanhol + carvoeiro: devido às manchas pretas que apresentam nos rostos lembran- 
do trabalhadores de carvoaria) são os nomes populares mais conhecidos do maior primata das Américas (chegando a pesar 15 quilos), o Brachyteles arachnoides E. Geoffroy, 1806 e Brachyteles hypoxanthus Kuhl, 1820. ${ }^{5}$ Possuem pelagem que varia entre tons de amarelo e cinza e caracterizam-se pela ausência do polegar oponível, no caso dos muriquis-do-sul, ou reduzido a um simples cotoco sem unha, entre os muriquis-do-norte - uma adaptação ao hábito de se balançar na copa das árvores.

O nome científico da espécie Brachyteles faz menção à sua forma de locomoção (braquiação) e é uma referência à família Atelinae a qual pertencem (ateles), juntamente com os macacos barrigudos, os barbados e os macacos-aranha (Strier 1992). O termo arachnoides é uma clara alusão à seu primo macaco-aranha, pois dele se aproxima em sua notável agilidade. Hypoxanthus é uma referência ao pequeno dedo polegar característico da espécie de muriquis-do-norte. A composição de seus nomes científicos, ou melhor, seus sobrenomes, é complementada pelo sobrenome do primeiro observador a descrevê-los e pelo ano em que foi realizada a descrição. Desta forma, a filiação termina respectivamente com "E. Geoffroy, 1806" e "Kuhl, 1820".

A espécie, que se acreditava extinta, foi redescoberta nas matas de Minas Gerais pelo conservacionista Álvaro Coutinho Aguirre na década de 1960, mas apenas em 1976, com a visita dos professores Célio Valle e Ney Carnevalli, da Universidade Federal de Minas Gerais, à Fazenda Montes Claros (MG), retomou notoriedade no circuito acadêmico (Fonseca \& Mittermeier 2003). O ressurgimento do mono-carvoeiro foi bastante explorado pela mídia em reportagens como a da revista Veja de 5 de janeiro de 1977, cujo título "A redescoberta do mono-carvoeiro na Fazenda Montes Claros" preconizava o retorno de uma espécie animal ao escopo do mundo dos humanos, posto que, de fato, era disso que tratava o parecer dos biólogos. Os muriquis, supostamente extintos, emergiam das matas para um novo contexto de convívio social, agora mediado por um sem-número de agentes. Ora, se os muriquis jamais haviam deixado de ser para seus interlocutores locais (fazendeiros, caçadores etc.), eles permaneceram anos a fio na condição de um não-ser, colocada por sua circunstância de animal extinto. Por outro lado, a mudança ocasionada por sua redescoberta por atores até então nada convencionais em suas relações cotidianas (biólogos e conservacionistas) ampliou a rede de significação da espécie, multiplicando suas imagens identitárias, mas também relegando aos antigos atores — para quem os macacos nunca haviam deixado de ser - os papéis coadjuvantes.

Desde então os muriquis têm sido foco de diversas pesquisas ligadas à biologia da conservação, ao comportamento animal e à ecologia de comuni- 
dades de plantas e animais que resultaram em teses e dissertações. A mais notória é a pesquisa de doutorado empreendida por Karen Strier, iniciada em 1982 com os muriquis de Caratinga, que deu origem ao principal livro já publicado sobre a espécie: Faces in the forest - the endangered muriqui monkeys of Brazil (Oxford University Press, 1992). Antes de vir para o Brasil com os auspícios de Irven DeVore, ${ }^{6}$ Russell Mittermeier, ${ }^{7}$ Celio Valle, Adelmar Coimbra-Filho ${ }^{8}$ e Ibsen de Gusmão Camara, a primatóloga havia estudado um grupo de babuínos na África. A perspectiva de pesquisar um grupo de primatas pouco conhecido trouxe Strier para o Brasil, dando origem a um bem sucedido plano de observação a longo prazo de primatas - em curso até os dias atuais - em que vários estudantes de graduação e pós-graduação brasileiros foram formados através da experiência de campo na Fazenda Montes Claros, sob sua orientação.

Com o passar dos anos, não foram apenas os estagiários que se multiplicaram. A própria população de muriquis estudada na reserva desenvolveu-se em uma progressão bastante animadora, muito além das expectativas dos conservacionistas, e com ela pluralizou-se sua própria categorização como espécie.

Se, como definiu Lévi-Strauss (1989:156-7), “[...] a noção de espécie possui uma dinâmica interna: coleção suspensa entre dois sistemas, a espécie é o operador que permite passar (e obriga mesmo a isso) da unidade de uma multiplicidade à diversidade de uma unidade", a dinâmica das sucessivas (re)classificações dos muriquis aponta para multiplicações rizomáticas deflagradas por agenciamentos diversos.

Os muriquis, na época em que reemergiram, eram tidos como uma única espécie, Brachyteles arachnoides, dispersa por diversos focos espalhados da Bahia ao Paraná. Com a descoberta de novas populações e o acúmulo de pesquisas, a população foi subdividida em duas subespécies: Brachyteles arachnoides arachnoides, que abrangia os grupos do Paraná e São Paulo, estendendo-se até o Rio de Janeiro; e Brachyteles arachnoides hypoxanthus, representativo dos contingentes encontrados na faixa que vai do leste mineiro ao sul da Bahia, atravessando o Espírito Santo (Strier 1992:10-1). Uma nova postura operou no sentido da reorganização taxonômica dos muriquis, concebendo-os como duas espécies distintas: os muriquis-do-sul (Brachyteles arachnoides E. Geoffroy, 1806) e os muriquis-do-norte (Brachyteles hypoxanthus Kuhl, 1820). Oficialmente, a promoção das subespécies à categoria de espécie obedece a critérios técnico-científicos em função de suas distintas morfologia e genética, além de experiências de cruzamento intergrupos que resultaram em indivíduos híbridos. Oficiosamente, comenta-se entre alguns pesquisadores que esta nova configuração foi em grande medida 
motivada pelo aumento significativo na população total de muriquis. Como consequência deste fenômeno, houve a exclusão dos muriquis da lista das espécies animais mais ameaçadas de extinção. A decisão político-científica de fragmentar a espécie teria sido tomada, portanto, no sentido de garantir a manutenção dos financiamentos para pesquisa e preservação de populações em risco de desaparecimento. O resultado destas ações é a estimativa de que, em 2003, 1.200 muriquis, entre muriquis-do-norte e muriquis-do-sul, sobreviviam nas regiões de mata, espalhados em uma faixa que vai do sul da Bahia ao norte do Paraná.

As estratégias oficiais e oficiosas, antes de representarem verdades absolutas ou oponentes, entre as quais se deve optar, tampouco indicam campos em disputa. As motivações de ordem política não contradizem as explicações técnicas, apenas as complexificam. Contudo, é possível que, antes de caracterizar uma oposição entre a teoria e a prática científica, essa ambiguidade entre oficial e oficioso dê conta de diferentes perspectivas do saber científico: uma, desejosa de fragmentações facilitadoras, e a outra, ansiosa pela complexificação problematizadora. Ambas pautadas empiricamente, cabe perguntar, afinal, o que seria menos real: animais que ao cruzarem dão origem a um indivíduo híbrido ou a redução das verbas para pesquisa?

Aproveitando o ensejo, há que se ponderar sobre as proposições de se produzir um tipo de análise sociológica dedicado ao estudo de ontologias oficiosas que fragmenta o universo nos mesmos polos antagônicos, epistemologia e antropologia, aos quais se opõe por princípio. ${ }^{9}$ Se "a ciência tende a pulverizar o universo, a multiplicar indefinidamente os seres [...] ela também tende nitidamente a unificar a dualidade cartesiana da matéria e do espírito" (Tarde 2003:31), penso que opor a epistemologia como lócus de purificação à antropologia como domínio do oficioso e cotidiano seja em certa medida compactuar com a combatida cisão moderna. Entendê-las como espécies distintas e propor a sua interação etnográfica não seria suficiente para superar o velho divisor, pois não é preciso ir muito longe para perceber que o produto desta relação será, de fato, um híbrido. É preciso pensar em sua reprodução. A reprodução dos híbridos: formas de pensar - artefatos oficialmente oficiosas e oficiosamente oficiais; naturalmente culturais e culturalmente naturais.

Minha intenção ao enfocar a construção da imagem do muriqui não é distanciar as concepções oficiais das oficiosas, mas colocá-las em diálogo sem ocupar-me desta partilha e, logo, inferir sobre a possível reprodução destes híbridos que, tal qual "a ciência após ter pulverizado o universo, termina necessariamente espiritualizando sua poeira" (Tarde 2003:45). 


\section{Os monos de/em Caratinga}

Apesar de conhecidos na região de Caratinga/MG apenas como monos, é dada preferência ao termo muriqui no meio acadêmico. Esta ênfase é percebida nas principais publicações sobre a espécie, inclusive em língua inglesa, em que convencionalmente eram chamados de woolly spider monkeys, uma clara composição por justaposição nominativa entre duas espécies distintas, woolly monkey (macaco barrigudo) e spider monkey (macaco-aranha), gerando uma terceira totalmente diferente (Strier 1992). Esta composição parece fazer menção à fisionomia das três espécies, uma vez que os muriquis são primatas que possuem um abdômen proeminente, como o dos "macacos barrigudos", membros longos e delgados, uma cauda preênsil, além de se locomoverem braquiando ${ }^{10}$ tal qual o macaco-aranha.

Entre os muriquis-do-norte (espécie que habita a RPPN em Caratinga), existem cerca de 500 indivíduos vivendo em habitat natural, distribuídos em pequenos fragmentos de mata nos estados do Espírito Santo e Minas Gerais. Na fazenda Montes Claros, a população de muriquis encontra-se em franco crescimento, como atesta a contagem de cerca de 90 indivíduos em 1996, passando a 170 em 2003 (Veado 2003; "Dossiê da EBC").

Aos 957 hectares que compõem a RPPN Feliciano Miguel Abdala, somam-se regiões vizinhas à reserva que ampliam o domínio da floresta atlântica em cerca de 1.450 ha. (Veado 2003). Esta é a área de utilização dos monos-carvoeiros, com suas lógicas sazonais de deslocamento e uso. Outras três espécies de primatas habitam a reserva: o barbado (Alouatta fusca), o sagui-da-serra (callithrix flaviceps) e o macaco-prego (Cebus apella). ${ }^{11}$ Para Strier, a coexistência não agonística entre as espécies de primatas da Estação é mediada de acordo com a disponibilidade de fontes alimentares e segundo a lógica de que

Os muriquis são dominantes; são maiores do que os outros. Mas os monos dominam mais por causa do tamanho individual e do grupo, eles não são bravos. Os barbados são mais devagar, mais preguiçosos, e os macacos-pregos são, provavelmente, das quatro espécies, os mais bravos [...] (Diário do Aço, 30/7/2000 - entrevista com Karen Strier).

\section{Bom para comer e bom para pensar}

A extensão da mata habitada pelos macacos transpõe as fronteiras da reserva. Sabe-se que os grupos de muriquis da RPPN frequentam as propriedades 
vizinhas ao menos em algumas ocasiões durante o ano. É comum, sobretudo para aqueles que trabalhavam no Jaó, seguir os macacos e cruzar os limites da Fazenda Montes Claros - nem sempre delimitados por cercas, mas indicados por pequenos tocos de madeira fixados no solo. Algumas regiões de mata mais distantes, ligadas por pequenos trechos à RPPN, eram suspeitas de abrigar alguns monos desgarrados dos grupos principais. Indivíduos que há anos não eram avistados entre os muriquis da RPPN poderiam ter sido predados ou mesmo migrado para terras circunvizinhas. Os boatos da existência de muriquis sobrevivendo em áreas próximas à reserva sempre circulavam e entusiasmavam os biólogos a realizar incursões em busca destes animais perdidos.

Certa vez participei de uma visita à propriedade de um fazendeiro vizinho, seguida de uma caminhada à procura de muriquis em seu pedaço de mata. Era um domingo da estação seca, e saímos de carro Catarina, Jerônimo e eu rumo à sede da fazenda ao lado. Já no meio do caminho, avistamos por trás de um morro uma volumosa coluna de fumaça negra que sinalizava uma prática comum na região: a realização de queimadas a fim de preparar o solo para o pasto e o roçado. Aquele indício que vinha da direção para a qual seguíamos parecia um mau presságio do que viria pela frente. Deixamos o carro próximo à entrada da fazenda e fomos ao encontro do velho fazendeiro, que nos aguardava em sua casa. A casa bastante rústica não fugia ao padrão das residências da região. A entrada nos levava a uma varanda, estilo sobrado, que dava acesso à ampla sala, com chão feito de tábuas de madeira já gastas pelos anos e solados de sapatos. Fomos recebidos aí.

Liderados por Jerônimo, o único de nosso grupo que conhecia o fazendeiro, sentamos lado a lado, encostados a uma parede. Sentado à mesa, junto à parede oposta, com olhar inquisidor, estava o velho fazendeiro. Ao seu lado, dois de seus filhos que também moravam na propriedade com suas respectivas famílias: de pé, ambos nos miravam intrigados. Fomos rapidamente apresentados por Jerônimo: Catarina como bióloga que trabalhava na Estação; eu como professor da universidade "lá do Rio de Janeiro". Seja lá o que aquilo de professor queria dizer, aceitei prontamente e acabei por não me arrepender, já que me distinguia da categoria "biólogo", que em seguida seria colocada na berlinda por nosso anfitrião.

O fazendeiro foi logo dizendo que "esses biólogos" que vinham da cidade acreditavam saber tudo sobre a vida na mata e que, sendo assim, pensavam poder legislar sobre a vida no campo. Todavia, falava o velho senhor diante de nossos olhares atônitos, eles [os biólogos] tinham muito o que aprender com os que trabalhavam a terra e que detinham, à sua maneira, o conhecimento empírico sobre aquela realidade. Tomei a liberdade 
de tentar pacificar aquela situação, dizendo que era justamente para isso que estávamos ali - para ouvi-lo. Em seguida, Jerônimo direcionou a prosa àquilo que motivava a nossa visita, perguntando sobre os monos e os macacos que apareciam em suas matas. Prontamente, o fazendeiro respondeu que ali existiam dois tipos de macaco, o barbado e o macaco-prego, mas que o mono já não havia mais. Disse ainda que, no passado, avistava frequentemente dois monos, mas que um deles logo desapareceu e que o restante (uma fêmea) havia se juntado a um grupo de barbados com quem inclusive teria procriado, mas que agora a fêmea remanescente já não aparecia mais, provavelmente tendo "morrido de velha".

Jerônimo havia nos alertado para o fato de que os moradores locais não consideravam o mono como uma espécie de macaco. Para eles, os macacos eram os barbados e os macacos-prego. ${ }^{12}$ Os monos compunham uma categoria à parte. Ainda assim, não era isso o que mais surpreendera Catarina. Nem mesmo o fato de um muriqui juntar-se a um grupo de barbados. A bióloga não se conformava com a ideia formulada pelo agricultor de que um mono-carvoeiro teria parido um filhote híbrido, fruto do cruzamento com um barbado. A reprodução não seria apenas improvável, tal qual a integração de um mono a um bando de barbados (embora admissível), mas biologicamente impossível. Segundo ela, a percepção equivocada do fazendeiro era obviamente fruto de sua escassa educação formal. ${ }^{13}$ Contudo, naquele momento, ouvíamos todos calados a explanação do dono da casa: o silêncio da bióloga ocultava seu incômodo, mas preservava a sua intenção de - passada toda aquela "baboseira" - explorar a mata daquela fazenda à procura de algum muriqui. O professor aqui, que tentava aprender um pouco sobre a cosmovisão daquelas pessoas, por fim acabava de ser brindado com o flagrante contraste entre os dois pontos de vista.

Se para a bióloga ainda era possível admitir a eventual adoção de um muriqui desgarrado por um bando de barbados, e mesmo a ocorrência de intercurso sexual entre eles (ainda que inviável reprodutivamente), o que diria sobre acatar os conselhos do fazendeiro sobre o manejo e forrageamento dos animais na mata? Pois foi justamente este o tópico que predominou e encerrou a nossa conversa de cerca de uma hora. O fazendeiro queixava-se das constantes investidas dos macacos-prego em sua lavoura, saqueando espigas de milho, que carregavam em seus braços atravessando estradas de terra em postura semi-ereta. Dizia que se os macacos-prego continuassem a agir daquela forma, ele teria de tomar providências, assustando — já utilizava cães com esse fim — ou mesmo eliminando alguns deles. ${ }^{14}$ Segundo o agricultor, a explicação para o aumento no número de invasões estava diretamente relacionada ao crescimento da população de macacos 
na reserva, que vinham em busca de alimentos nas plantações vizinhas. Ao que tudo indica, pelo menos neste ponto as interpretações de biólogos e fazendeiros convergiam. Contudo, voltavam a divergir quanto ao papel e ao direito de humanos e animais se relacionarem com a terra. Para a bióloga, os verdadeiros invasores eram os seres humanos, que historicamente vinham restringindo o espaço vital dos animais em pequenas ilhas de floresta rodeadas por áreas de plantio.

As soluções para o impasse eram igualmente antagônicas. Enquanto os biólogos advogavam o abandono das terras cultiváveis em nome do replantio de mudas nativas e da pronta regeneração da mata, possibilitando a ampliação do espaço útil dos animais, o fazendeiro, por sua vez, criticava o replantio de mudas de árvores nativas, dizendo que estas não mais agradavam ao paladar dos animais, e argumentava que os biólogos deveriam estimular o plantio de lavouras de milho dentro da própria reserva biológica, pois assim os macacos não precisariam buscar alimentos fora do perímetro da mata.

Embora suas posições pareçam diametralmente opostas, tanto biólogos como fazendeiros aproximam-se em seus discursos. A ideia de que os macacos buscam alimentos é compartilhada, assim como a noção de que monos e barbados poderiam conviver num mesmo grupo. A cisão acontece ao se tentar determinar aquilo que "realmente" é alimento para os macacos. Partindo de sua observação cotidiana, o fazendeiro entende que a alimentação do macaco é composta por frutos e folhagens da mata, mas que ele [o macaco] prefere comer algo da própria dieta humana [o milho]. Afinal, se fosse o contrário, não sofreria com os ataques à sua lavoura. Por outro lado, o biólogo vê nas incursões ao milharal uma resposta à diminuição das fontes alimentares naturais da mata, visto que organiza seu raciocínio do seguinte modo: comida de gente deve ser naturalmente diferente de comida de bicho. O fazendeiro surge com uma disrupção cultural à lei, pois oferece ao bicho uma escolha, determinando-lhe uma preferência. Pode até ser acusado de culturalizar o animal, mas da forma como se opõe a comida de gente à comida de bicho, fragmenta-se também a relação que vê na convivência entre muriquis e barbados algo possível. Ora, se do ponto de vista do fazendeiro é possível conviver pacificamente, independentemente de separações classificatórias $($ mono $=$ não macaco, barbado $=$ macaco $)$, também seria plausível e esperado que estes procriassem. Do contrário, de que outro modo conceber esta união estável senão como propícia a gerar descendentes? Por outro lado, a divisão especista sustentada pelos biólogos impõe limites a esta relação, ao inviabilizar qualquer possibilidade de reprodução. Atente-se para o fato de que, se para os fazendeiros as diversas classificações não impediriam o estabelecimento de relações entre os termos — estando naturalmente nor- 
teadas por uma lógica que prevê a procriação como uma finalidade em si para os biólogos, a relação entre os termos (monos e barbados) é orientada por necessidades não tão imperiosas quanto a procriação. Segundo eles, o convívio entre indivíduos de duas espécies distintas seria uma possibilidade, rara mas factível, sem jamais vincular-se ao ato de deixar herdeiros. Vista desta forma, a lógica dos biólogos está calcada num enrijecimento de termos - duas espécies não hibridizáveis - e numa flexibilização no tipo de relação, pois a escolha pela convivência pode se dar em função de diversos fatores. Para o fazendeiro, o inverso é mais provável. Mesmo que os termos já estejam dispostos, eles podem ser reorganizados e repensados a partir da lógica da relação que os une, o que confere uma motivação (um sentido) mais perene em face de uma classificação preexistente que, por sua vez, se torna mutante, adaptável e transitória.

Se os biólogos, neste caso, pressupõem certo fixismo identitário, eles constroem em torno desta caixa-preta cosmos especistas paralelos. Ou seja, mundos autônomos nos quais ideias como "a casa dos macacos é a mata", "comida de macaco é parte de vegetação nativa" etc. equivalem a noções simétricas inversas como "casa de gente é na cidade e milho é comida de gente". Verifica-se aqui uma incômoda - para os mais cautelosos - aproximação da ideia formulada no âmbito do perspectivismo ameríndio na qual os animais se veem como humanos porque os humanos os veem como animais, vendo-se a si mesmos como humanos (Viveiros de Castro 2002b). E complementamos acionando a condição de possibilidade central das cosmologias naturalistas: podemos pensar assim porque, em última análise, compartilhamos de uma animalidade comum de origem.

A narrativa citada indica sobreposição desses mundos/naturezas paralelos e apresenta personagens que transitam entre eles, causando interferências na cosmologia naturalista (biológica, científica). Resumindo, se é possível falar em um mundo do ponto de vista do fazendeiro, este seria um mundo compartilhado, no qual categorias como a de invasor, alimento, habitat, mono e macaco etc. seriam constantemente atualizadas a partir da prática cotidiana, ao contrário do que é verificado no discurso dos biólogos, em que estas categorias se encontram predispostas, as relações emergindo de permutações entre elas.

\section{A propósito do (bom) comportamento}

As práticas comuns de categorização, seja segundo os habitantes locais, particularizando o mono como um "ser" ("macaco" ou "não macaco") ou, 
para os biólogos, classificando o muriqui como espécie, aproxima ambos os grupos. Entretanto, para nos aprofundarmos na construção destas "categorias nativas" sem pressupor um alicerce dicotômico opondo visões naturalistas àquelas animistas, é preciso averiguar a forma como os primatólogos entendem o comportamento dos muriquis e, posteriormente, suas motivações ao classificá-los.

Os bandos de muriquis são formados por indivíduos machos e fêmeas adultos, além de filhotes de várias idades. Geralmente subdividem-se em dois grandes grupos: o dos machos e o das fêmeas com os filhotes. Os machos costumam se manter unidos, formando um grupo coeso que, ao se deslocar, forma uma fila de indivíduos braquiando um atrás do outro. As fêmeas costumam separar-se umas das outras e, como dizem os pesquisadores em campo, ao contrário de outras espécies de primatas nas quais os machos cercam o grupo de fêmeas e filhotes a fim de protegê-lo, na sociedade muriqui, o "centro é masculino e a periferia é feminina". Porém, esta é apenas a primeira das especificidades em oposição a outros modelos primatas.

Após uma gestação que dura sete meses, a fêmea concebe geralmente apenas um filhote, ${ }^{15}$ que inicialmente será transportado junto ao seu peito. Antes de adquirir independência para se locomover sozinho, o filhote passa a ser carregado nas costas da mãe. ${ }^{16}$ Após o nascimento da cria, a fêmea estará novamente apta a procriar em aproximadamente três anos. Ainda que não se disponham de dados precisos estimando a duração de seu ciclo de vida em ambiente natural, sabe-se que os machos atingem a maturidade sexual aos cinco anos e meio e que as fêmeas jovens costumam migrar para outros grupos. A descoberta de que são as fêmeas que migram de uma população para outra contraria outro padrão comum entre as espécies de primatas sociais, em que o inverso seria observado. Este dado, atribuído às observações de campo de Strier, é relevante por se tratar de uma espécie ameaçada de extinção, para a qual serão possivelmente elaborados programas de manejo no intuito de se evitar os problemas causados pela pouca variabilidade genética. Neste sentido, a escolha de alguns indivíduos a serem transferidos de uma população para a outra deveria nortear-se por aqueles que "naturalmente" iriam migrar em determinado momento de suas vidas. Se os padrões usuais da maioria dos primatas fossem adotados para o caso muriqui, este seria um erro fatal, pois aqui são as fêmeas, e não os machos, que deveriam ser remanejadas.

As observações sobre o comportamento social muriqui deram origem a diversas teorias, discursos e imagens difundidos pelos que advogam em favor de sua singularidade entre as demais espécies de primatas sociais. O sistema social flexível, a pouca agressividade (raramente brigam), a au- 
sência de disputa pela dominância do grupo ou pelo acesso às fêmeas são fatores que os distinguem da maioria dos outros primatas. Em torno desta especificidade, Strier erigiu sua teoria sobre o comportamento social muriqui. Apesar de apontar para as diferenças singulares, a pesquisadora partiu de um modelo teórico proposto por Wrangham $(1979 ; 1980)$ denominado socioecologia, que propõe basicamente que o comportamento social dos primatas pode ser determinado através do estudo do potencial ecológico de seu ambiente. Segundo Wrangham, as formas de alimentação influenciam diretamente o sucesso reprodutivo dos machos e principalmente das fêmeas, estabelecendo assim indicativos dos padrões da organização social de cada espécie. Esta correlação entre as condições ecológicas e a estrutura social é desenvolvida pela teoria de que o ambiente forja o comportamento de cada espécie e de cada sexo diferentemente. A distribuição do alimento que pode ser farta ou escassa, centralizada ou dispersa - irá determinar o quão gregárias são as fêmeas de determinada espécie. Wrangham observou o comportamento de 28 espécies, deduzindo que, em geral, as fêmeas se alimentam juntas quando o alimento é farto e encontrado em grandes fontes - condições que oferecem comida suficiente para todos os membros do grupo, protegendo-os de invasores. Quando essas fontes encontramse temporariamente esgotadas, as fêmeas suprem a sua dieta com outros alimentos. Wrangham dá o exemplo das fêmeas babuíno da savana, que vivem em grupos porque seus alimentos favoritos, frutos e flores, crescem em grandes moitas fáceis de defender. As fêmeas formam relacionamentos duradouros e estabelecem hierarquias estáveis da dominância. Este estilo de agrupamento coeso define as possibilidades de acasalamento para os machos, que têm apenas de excluir os demais competidores. Desta forma, um bando de babuínos é composto por um clã feminino acompanhado por um número de machos, que competem entre si para conseguir acesso às fêmeas. Logo, para os babuínos, existiriam poucas vantagens na cooperação fraternal e muitas na competição. Portanto, a diversidade ecológica influenciaria na estrutura social do grupo de fêmeas, que determinaria a variabilidade no comportamento social das espécies (Wrangham 1980).

Este pressuposto teórico inspirou Strier em sua pesquisa com os muriquis e foi devidamente adaptado às condições dos primatas "brasileiros" e às observações de campo da pesquisadora. A avaliação do modelo proposto por Wrangham, no caso muriqui, resultou no estabelecimento de um novo padrão que fugia um pouco daquele inicialmente proposto. O comportamento das fêmeas alinhava-se ao predisposto por Wrangham para os babuínos: elas permaneciam unidas em torno de uma determinada fonte alimentar, que defendiam na presença de intrusos. Esperava-se, consequentemente, que 
a competição entre os machos fosse acentuada como no caso dos babuínos. Entretanto, o comportamento dos muriquis contrariava qualquer padrão já inventariado: não foi verificado qualquer tipo de competição entre os machos do grupo.

Esta divergência em relação ao modelo original deu origem a uma leitura própria da socioecologia muriqui. A explicação encontrada por Strier para a ausência de agressividade entre estes primatas segue uma linha de raciocínio que equaciona riscos de acidentes, acúmulo energético e maximização da capacidade reprodutiva dos machos. Segundo ela, os muriquis encontram-se no limite de peso e tamanho ideal para possibilitar seu tipo de locomoção braquiando rapidamente na copa das árvores. Se fossem maiores, além do comprometimento da velocidade de locomoção, haveria um aumento no número de quedas, o que configuraria um alto risco para a espécie. Em função deste risco, é pensada a predisposição em se evitar brigas que, além de causarem danos, representariam um dispêndio de energia acima do que os muriquis conseguiriam acumular através da ingestão calórica (Milton $1984 ; 1985 b)$. Segundo Strier, os limites que a rápida braquiação impõe a seu tamanho e a escassa energia passível de ser gasta em um eventual combate desestimulam a competição entre os muriquis.

Outro (arte)fato que os transforma em uma "exceção à regra" diz respeito às mesmas proporções de machos e fêmeas, característica incomum em sociedades animais políginas como a dos muriquis. A seleção sexual darwiniana atuaria sobre somente um dos sexos, diferentemente da ideia de seleção natural, acentuando o dimorfismo sexual através de diferenças fenotípicas dentro de cada espécie. Na maioria das sociedades políginas, ser um macho maior representa uma vantagem na disputa pelas fêmeas e consequentemente na perpetuação de seus genes, acentuando de geração em geração esta característica fenotípica "vantajosa". Contudo, na sociedade muriqui, a seleção sexual parece ter agido de forma a não favorecer os indivíduos machos maiores em função dos riscos e dispêndios já descritos acima. Isto determinou um profundo efeito no comportamento social muriqui. Ter o mesmo tamanho dos machos faz com que as fêmeas não possam ser dominadas por eles. Sendo assim, elas podem escolher seus parceiros. As fêmeas copulam livremente com diversos machos do bando, da mesma forma que se recusam a fazê-lo com indivíduos indesejados. Tudo indica que lutar não beneficiaria em nada o macho muriqui, já que a fêmea tenderia a evitar aqueles mais agressivos. ${ }^{17} \mathrm{O}$ argumento de Strier direciona-se, portanto, a outro mecanismo adotado pelos muriquis capaz de garantir a seleção sexual e o sucesso reprodutivo: a "competição de esperma". Esta ideia, muito popular entre sociobiólogos durante as décadas de 1980 e 1990,18 ganhou 
força na primatologia a partir de estudos sobre o comportamento sexual dos chimpanzés e foi prolongada até os muriquis como explicação para a posse de enormes testículos (Milton 1985a; 1985b). Neste tipo de competição, um indivíduo macho tenta copular o maior número de vezes com as fêmeas a fim de que seu esperma tenha mais chance de prevalecer em relação ao dos outros, dando origem às futuras crias. No caso muriqui, este panorama torna-se complexo, pois as fêmeas tendem a copular com um grande número de machos - muitas vezes em sequência - pouco adiantando qualquer tentativa masculina de conseguir exclusividade de sua parceira (como acontece no caso dos chimpanzés). Além disso, as fêmeas muriquis não apresentam qualquer indício aparente de seu período fértil, como em outras espécies de primatas. Diante desta situação, os machos estariam compelidos a copular sempre que as fêmeas se mostrassem disponíveis, aumentando proporcionalmente as suas chances de "contrair" paternidade. Strier pondera que o aumento no número de cópulas diminuiria consideravelmente a quantidade de esperma produzido, o que poderia configurar uma desvantagem para este indivíduo. A solução para esse impasse, forjada no processo de seleção sexual ao longo de inúmeras gerações, foi conceder alguma vantagem reprodutiva aos indivíduos que possuíssem os maiores testículos, capazes de produzir regularmente maior quantidade de esperma. Segundo a pesquisadora, isso explicaria os grandes testículos característicos dos machos da espécie.

\section{Em algum lugar entre o cachorro e o ser humano}

O antagonismo entre os muriquis e os babuínos fica ainda mais evidente ao se avaliar retrospectivamente o contexto histórico das décadas de 1950 a 1970, quando predominava o "modelo babuíno" na primatologia. Egressa de uma ideologia reificada no célebre seminário Man the hunter, a sociedade babuína oferecia estereótipos das relações entre machos e fêmeas que se alinhavam ao protocolo de estudos da biologia evolutiva do período do pós-guerra. O foco dos estudos primatológicos nos machos dominantes em detrimento das análises dos grupos de fêmeas e filhotes e machos periféricos apontava para um viés masculinista presente na produção científica (Schienbinger 2001:244). A escolha dos babuínos como principal objeto da primatologia atendia a certos preceitos de época: eram macacos que viviam no solo, ao contrário da grande maioria dos primatas, o que os tornava mais acessíveis à observação; habitavam a savana africana (considerado o local de surgimento do "homem primitivo") e por isso compartilhavam as mesmas pressões seletivas dos proto-hominídeos; portanto, a ideia de uma sociedade 
primata agressiva, competitiva, hierarquizada e dominada pelos machos era bastante coerente com o cenário erigido durante a Guerra Fria. Desta perspectiva, os "babuínos forneciam uma explicação pronta para a guerra e a violência humanas e a agressão masculina" (Schienbinger 2001:246), a despeito do fato de que outras espécies pudessem fornecer visões mais otimistas dos ancestrais dos humanos.

Um desvio inusitado no argumento acerca do papel dos babuínos foi verificado em uma conversa que tive com um primatólogo da Estação Biológica de Caratinga, que criticava a generalização dos modelos baseados nestes primatas. Segundo ele — falando em tom jocoso — os babuínos, muito em voga nas décadas passadas, não forneciam parâmetros confiáveis para o estudo de outros primatas. Dizia em meio a uma risada: "babuínos são mais parecidos com cachorros!"

Sem esvaziar o conteúdo sociológico investido na crítica feminista, o comentário do primatólogo redimensiona a grande variabilidade de impressões existente nas relações entre humanos e primatas não humanos, inclusive no contexto das relações entre primatólogos e primatas.

Ainda que não admitisse ter sido motivada pelo que Schienbinger (2001) chamou de "preocupações feministas" e tampouco se considerasse uma "primatóloga feminista", a migração de uma das principais pesquisadoras da Estação, do estudo de babuínos ao de muriquis constituiu um deslocamento tanto físico quanto teórico. Seu novo olhar, distanciado daquilo que se passava entre babuínos, parece ter dado margem à consolidação do papel das fêmeas muriqui. Rompendo com o estereótipo de passividade, estas surgem como o sustentáculo de uma sociedade não sexista, não agressiva, não hierarquizada e sexualmente libertária. Aqui há uma aparente aproximação — ainda que jamais tenha se concretizado — da proposta de Strier àquela promulgada pela teoria sociobiológica acerca dos primatas (Haraway 1989): reelaborando os processos de seleção sexual, ela condiciona o tamanho dos machos à mesma proporção das fêmeas, bem como acentua o comportamento "pouco tímido" das últimas. Entretanto, invertendo o panorama das narrativas feministas-sociobiológicas, no qual tanto machos como fêmeas são agressivos, competitivos e lutam por vantagens genéticas (Hrdy 1981), Strier sugere que os mesmos fins podem ser alcançados através de meios distintos, ainda que determinados por restrições ecológicas.

No que diz respeito à construção da imagem de seus respectivos objetos, tanto as primatólogas-sociobiólogas-feministas quanto Karen Strier demonstram ter sido bastante eficazes e coerentes com suas próprias teorias. As primeiras, "acusadas de produzir a 'primata executiva': babuínas com maletas, estrategicamente competitivas e agressivas" (Schienbinger 2001:253), ${ }^{19}$ e a 
última produzindo o "macaco hippie". Strier antecipa a condição que será atribuída aos muriquis como uma opção específica em meio ao universo de humanos e não humanos: "O comportamento dos muriquis na mata aponta para uma perspectiva de vida diferente da nossa", diz ela encontrando respaldo em sucessivas reportagens sobre os muriquis.

A sociedade pacifista é uma característica do gênero, pelo menos em condições de equilíbrio ambiental e alimentar. Independente da proximidade evolutiva, o estudo dos primatas é uma referência para entendermos melhor a própria condição humana. Tenho muito respeito pelos muriquis. Eles me ensinaram a ser o tipo de humano que eu sempre desejei (Strier para Globo Rural, ano 13, n.149, março 1998).

Destaca-se a semelhança da proposição de Strier com o relato de Jane Goodall, por ocasião da morte de uma velha chimpanzé por ela estudada:

Fazia uma manhã límpida e luminosa quando recebi a notícia da morte de Flo. Seu corpo tinha sido encontrado, caído de rosto para baixo, no riacho Kakombe. O fato de eu saber há muito tempo que o fim estava próximo não amenizou nem um pouco a dor que senti, ali de pé, olhando os restos mortais de Flo. Eu a conhecia há onze anos e a amava.

Fiquei de vigília junto ao corpo dela naquela noite, para impedir que algum animal faminto a atacasse [...] E muita coisa aprendi com ela durante essa longa amizade. Pois ela me ensinou a valorizar o papel da mãe na sociedade e a compreender não apenas a importância incomensurável que os cuidados maternos têm para um filho, mas também a alegria e a satisfação profundas que esse relacionamento pode representar para a mãe (Goodall 1991:42).

Na mesma linha, situa-se o comentário de Dian Fossey acerca de um de seus grupos de gorilas da montanha:

Mais do que qualquer outro entre os cinco grupos estudados de Karisoke, os membros do Grupo 5 me ensinaram como sólidos laços de parentesco contribuem para a coesão de uma unidade familiar gorila ao longo dos anos. O êxito do Grupo 5 fornece um exemplo comportamental para a sociedade humana, uma herança que nos foi legada por Beethoven (Fossey 1983:105).

Em todos os casos, está presente a ideia de que os primatas não humanos têm algo a nos ensinar. Aprender com os primatas, nestes casos, não significa aprender como é "ser primata", mas o que é "ser humano". ${ }^{20}$ Esta 
proposição, ao mesmo tempo em que rompe com a simples ideia de projeção humana sobre os não humanos, também contempla a de que o seu inverso seria a projeção animal/natureza sobre a condição humana/cultura. Mais do que isso: os primatas promoveriam o humano em nós.

Os dados obtidos por Strier deram origem a uma nova visão sobre os muriquis, prontamente acolhida pela mídia e divulgada como mote conservacionista, científico e até mesmo filosófico. Se ideias tais como os monos “[...] não atacam o homem e nem devastam as plantações. Os machos convivem pacificamente, ao contrário de outros primatas, entre os quais existe a luta pelo poder" (O Globo, 10/1981) sempre emergiram em oposição a outros modelos de comportamento entre primatas, por outro lado, quanto mais se acumula conhecimento acerca dos primatas, mais visíveis e independentes eles se tornam em relação ao trabalho dos primatólogos (Latour 2000:370). A sugestão de que o muriqui seria um primata atípico foi construída através de uma verdadeira ode à sua escassa agressividade, à sua tolerância e à ausência de uma hierarquia social definida, o que dá margem a suspiros de igualdade saudados por pesquisadores e ambientalistas. Autonomia e dependência se entrelaçam nesta equação, em que o que é construído é feito para agir, ou ter agência, sobre os construtores. E, como um fluxo torrencial, não devemos nos surpreender se através desta categorização dos muriquis como "un-monkeylike" os biólogos reaproximarem-se do pensamento dos habitantes locais para quem os monos efetivamente não são macacos.

As imagens paracientíficas nutrem-se de informações extraídas de um contexto teórico baseado em experiências com personagens reais. Como na brincadeira infantil de telefone-sem-fio em que a oração original vai sendo transformada na medida em que é retransmitida aos sussurros, de jogador a jogador, a vida dos muriquis é redefinida em manchetes como: "A mais curiosa de todas as características dos muriquis, no entanto, está no que os seres humanos consideram uma extravagante promiscuidade das fêmeas" (Horizonte Geográfico, 41, 1995); ou ainda "No momento do sexo tudo é mais tranquilo. Cada macaco no seu galho espera a vez de copular com a insaciável e exigente fêmea muriqui, que prefere se relacionar com os mais velhos" (Os Caminhos da Terra, 4(8), edição 40, agosto 1995). No fim do jogo, o sujeito que originalmente gerou a informação é chamado a decodificá-la, purificando-a até sua forma original, na qual ficará claro que a evocada "promiscuidade" está ligada aos relatos de campo (Strier 1992; Milton 1985a, 1985b) que narram cenas do comportamento sexual dos muriquis em que machos se organizam "em fila" aguardando calmamente sua vez de copular com uma única fêmea. Sob esse aspecto vigora a observação de que a pureza é uma característica do estado bruto do enunciado e que, 
na medida em que este é trabalhado, são anexados novos complementos, tornando-o ao mesmo tempo mais complexo e de mais fácil perpetuação. Assim, seu destino, após ter sido massificado é a reciclagem purificante executada pelo próprio agente deflagrador.

A polarização entre o modelo dos babuínos, belicosos e violentos, em oposição ao dos muriquis, pacíficos e amorosos, é acompanhada por vários outros exemplos de imagens construídas, desconstruídas e reconstruídas de outros primatas. É neste sentido que Latour (2000) subverte a lógica corrente mais radical da "construção social", argumentando que os principais responsáveis pela mudança na forma de vermos os primatas são os próprios primatas. Segundo ele, ao longo dos anos, os objetos de estudo dos primatólogos desvelaram-se, objetivando a criação de novas alcunhas e novos modelos interpretativos. Este seria o caso do gorila, descrito até o início do século XX como uma "terrível criatura selvagem", "metade homem, metade fera" (National Geographic, 117(1)) e que, a partir da década de 1960, em grande parte devido ao trabalho de campo de Dian Fossey, passou a ser conhecido como um "gigante gentil". Os chimpanzés também transformaram-se em seres "políticos" e habilidosos num processo semelhante ao que concedeu a alcunha de "macaco Kama-Sutra" aos bonobos, graças à sua prática de copular em diversas posições e pelo fato de sua sexualidade estar dissociada da função reprodutiva (Picq 2002:38). ${ }^{21}$ De acordo com Latour (2000), a principal contribuição dos primatólogos para esta mudança é a postura de "to give the opportunity to behave" aos primatas, que em nada se assemelha a "incutir um viés" sobre eles. A função dos cientistas seria a de conceder uma oportunidade para que os animais possam se desvelar, ou seja, seria o primeiro passo para torná-los públicos. É algo muito diferente de "inventar" um animal ou algo sobre ele. Deixar que o próprio se revele está eventualmente condicionado a realizar aproximações circunstanciais, como demonstra o caso de Thelma Rowell: no "giving the opportunity to behave", as ovelhas por ela estudadas comportaram-se, para ela, similarmente aos chimpanzés. Não por acreditar que efetivamente fosse assim, mas porque tratá-las como "animais carismáticos" como os chimpanzés subverteria o entendimento de que ovelhas são "animais tediosos". Afastando tal pressuposto, seria possível que novos traços e características das ovelhas se fizessem visíveis. Através desta articulação artificial funcionaria o estratagema capaz de "dar uma chance" aos animais para que possam revelar o que realmente são (apud Latour 2000:367-8).

Estas articulações identitárias não configuram situações estáveis das quais poder-se-ia deduzir algum comportamento "natural". Pelo contrário, elas são nódulos que revelam profunda instabilidade e tensão naquilo que 
podem vir a ser estes animais, criando condições maleáveis de relações políticas, afetivas e científicas e transformando a trajetória destes coletivos. É a partir destes encontros que se redefinem as identidades acionadas para retroalimentar toda a cadeia de observação-investigação-teorização-divulgação-financiamento na primatologia, também denominada por Latour (2000) de "fluxos de conhecimento" (mobilização do mundo - autonomização da disciplina - alianças e interesses — relações públicas da disciplina — conceitos).

\section{O macaco hippie}

Inseridas em uma ampla rede composta por diversos personagens e objetos, estas noções "arranhadas" pela mídia fazem parte de um mecanismo que se retroalimenta, às vezes purificando e outras profanando a tradução científica. Partindo de uma "profanação" aparece pela primeira vez na imprensa local uma imagem que será explorada por pesquisadores e conservacionistas para a captação de recursos: o macaco "hippie".

De acordo com a constatação do biólogo, outras espécies de macacos têm a vida mais agitada, ao contrário do mono, que apresenta um comportamento "hippie". Enquanto nas outras espécies há sempre um líder, que é o mais bravo e por isso tem a preferência da comida e da fêmea, com os monos a coisa é diferente. Eles não brigam pela comida e cada um espera, pacificamente, a vez para um relacionamento sexual com a fêmea. O mono mais querido e respeitado é amável e delicado com os demais do bando (Leste Hoje, n. 48, 16/10/1990).

Da forma como se distingue dos demais primatas em organização e comportamento social, os muriquis são paulatinamente aproximados do mundo dos humanos. A forma como isto se dá reflete de diversas maneiras sobre os coletivos humanos e muriquis. A referência ao comportamento pacifista e "libertino" dos hippies fornece uma metáfora vigorosa do mundo dos humanos, originalmente ligada àquela em que a "Mãe muriqui não é punitiva: é doce e paciente, protetora como as nossas mães índias" (Globo Rural, ano 13, 149, 1998). O que dizer dos casos em que associações de matriz utilitária são evidentes?

Russell Mittermeier, no início dos anos 1980, então coordenador do World Wildlife Fund (WWF), chama a atenção para a relevância da preservação do mono-carvoeiro, segundo ele "extremamente importante para o desenvolvimento de pesquisas antropológicas, já que sua morfologia é a 
que mais se aproxima da dos antepassados do homem" (Estado de Minas, 29/6/1980). ${ }^{22}$ Em outra entrevista concedida no mesmo período, Mittermeier reafirma serem os monos-carvoeiros os primatas com a "morfologia mais semelhante à do homem", acrescentando que "Esses modelos [o dos macacos] são insubstituíveis para a pesquisa biomédica" (Revista Veja, 28/11/1979). Sua posição será ratificada pelo professor Adelmar Coimbra Filho, do Departamento de Conservação Ambiental do Estado do Rio de Janeiro, para quem o mono-carvoeiro serviria de excelente "teste para pesquisas que vão da malária ao câncer". Dizia ele, "Se a talidomida tivesse sido testada num desses animais [...] certamente ter-se-ia evitado uma grande tragédia" (idem). Ainda que os argumentos a favor da preservação do mono devam ser contextualizados, não deixa de surpreender o fato de que, anos mais tarde, sob a alegação de que "numa faixa de floresta Atlântica no Espírito Santo, um médico teria abatido a tiros cerca de 15 muriquis para realizar pesquisas relacionadas sobre a semelhança de seu fígado com o do homem" (Cartas de Minas, maio de 1987), o mesmo tenha sido severamente criticado pelos naturalistas.

Se, por um lado, junto à nova moral conservacionista mantinha-se o argumento de que os muriquis eram os "most ape-like Neotropical primate species", tão próximos de nós que "Um pequeno resfriado humano pode levar à dizimação total dos muriquis" (População e Desenvolvimento, setembro/outubro de 1989), por outro, o discurso utilitarista em torno da preservação do muriqui começa a ser substituído por um outro, impregnado de apelo simbólico.

Em seu entendimento não se pergunta qual a utilidade do mono ou das obras de Picasso. Há um valor moral em qualquer forma de vida que deve ser respeitada pelo homem, já que a própria essência da vida, a reciclagem da energia, passa pelos seres vivos. O homem deve respeitar o ciclo evolutivo de qualquer espécie (Célio Valle. Cartas de Minas, maio de 1987).

Esta nova lógica discursiva emerge de um contexto global que pretende promover o mono-carvoeiro a símbolo ou exemplo de medidas viáveis para o resgate de espécies em risco de extinção. Segundo o próprio Mittermeier:

Se o muriqui desaparecer, nada mudará na economia mundial. Mas este é um ponto exemplar. Se nós conseguirmos salvar o muriqui, nós poderemos salvar centenas de outros. O muriqui é uma boa escolha para enfocarmos em uma cruzada pela conservação. É o que está mais próximo dos símios - e, portanto, mais próximo dos humanos — dos chamados macacos do Novo Mundo. É o 
maior macaco das Américas (embora seja menor do que um chimpanzé africano), e sua graciosa habilidade para se locomover entre as árvores faz dele um animal excitante de se ver (The Journal Times, 10/4/1983).

O muriqui tornara-se uma bandeira internacional em prol da preservação das espécies e seria gradativamente trabalhado como um ícone da fauna brasileira. A mobilização internacional que, ao cabo, se transformava em financiamento para pesquisas científicas, demandava medidas locais para a conscientização da população e dos órgãos públicos sobre a importância da espécie. Incluídos na lista de animais da Fauna Brasileira Ameaçada de Extinção, publicada no Diário Oficial da União em 22 de dezembro de 1989, os muriquis passaram a ser vistos como uma espécie tão importante para o Brasil quanto o tigre para a Índia, o panda para a China e o gorila para o continente africano.

A estratégia adotada no caso brasileiro orientava-se a partir de outras experiências que haviam transformado uma determinada espécie em animal totêmico de um país ou região. A dinâmica transnacional conservacionista propunha a nacionalização do mono-carvoeiro: de patrimônio das matas do Seu Feliciano, os monos passariam a patrimônio nacional, almejando o status de patrimônio natural da humanidade. Paralelamente, a centralização dos esforços na preservação do mono-carvoeiro também ocultava uma questão de fundo acerca da preservação de seu habitat, como explicita o primatólogo Francisco Dyonísio Mendes:

Um outro lance de importância, quer dizer, o próprio conservar o mono. Na realidade o mono tem uma importância muito grande porque ele é uma bandeira para a conservação da mata Atlântica; ninguém tá aqui para conservar o mono, na verdade isso é uma mentira que a gente usa porque o mono chama atenção, é um bicho grande, bonito de ver, e as pessoas dizem: "Pô, que maldade matar esse bichinho! É tão bonito, parece tão humano". Então a gente usa isso porque, para se conservar o mono, você tem que conservar a casa dele (Tablóide Esportivo, 05/7/1991).

Na prática, diversas iniciativas foram tomadas a fim de divulgar a causa dos muriquis - ou pelo menos aquela dos que os pesquisavam.

Correr a maratona de Nova Iorque vestindo uma camiseta ilustrada com a fotografia de um muriqui, empreender campanhas internacionais para angariar recursos, indicar o muriqui através da SBPC e FBCN como animal símbolo do Brasil, comercializar "kits" escolares com fotos destes animais, emitir bilhetes de loteria federal estampados com o perfil de um muriqui, ou até mesmo o lançamento de uma campanha nacional intitulada 
"Seja humano, salve o mono!". Todas estas iniciativas de vulgarização da imagem do muriqui resultaram em um aumento circunstancial dos recursos para pesquisa, gerando maior interesse da mídia não especializada nos primatas da Estação, além de algumas manifestações bem-humoradas por parte da população local.

Em 1990, durante o período que precedeu o pleito eleitoral para governador do estado de Minas Gerais, um grupo lançou uma jocosa campanha cujo slogan era "Seja um mono, salve um humano". ${ }^{23} \mathrm{O}$ candidato fictício concorreria ao cargo público pelo partido "Movimento Social de Mono" (MSM), sob a legenda "65" (número do macaco no jogo do bicho). Apesar das críticas feitas pela imprensa local - "Os que assim estão procedendo dão mostras de que seus cérebros são menores que os dos macacos que vivem na Fazenda Montes Claros" (A Semana Caratinguense, 4/11/1990) - a brincadeira dava indícios da recomposição da imagem do mono-carvoeiro pelas camadas urbanas que já haviam assimilado o modelo/imagem de comportamento que mídia e biólogos passaram a adotar acerca dos macacos.

O jogo de palavras invertidas no slogan das campanhas conservacionista e "eleitoral" torna a ideia de ser "humano" uma variável condicionada a determinado comportamento "humanitário". No primeiro caso, a humanidade é evocada como atributo capaz de intervir e decidir sobre o destino de outrem: a humanidade em seu fator distintivo, cultural, do universo animal, ou como propõe Ingold (1994), o ser humano como condição, ainda que discriminado como espécie. A segunda situação, ainda que proveniente de uma piada, nos leva à outra face da mesma moeda. A proposição "Seja um mono, salve um humano" possui radical comum com a ideia de "macaco hippie" forjada por biólogos e pelo marketing conservacionista. O que está em jogo é como "ser um mono" nos possibilitaria questionar a própria condição humana. Se no passado a metáfora primata da natureza humana provinha dos babuínos e de seu estilo de vida que refletia sobre um contexto hobbesiano de competição, no presente, ela é projetada segundo a adoção de luzes rousseaunianas do muriqui como alternativa para o futuro humano.

O muriqui pode não ser o paradigma original, o primata típico perseguido pela antropologia. Com certeza também não oferece a elucidação definitiva para a natureza remota do homem - se é que isso existe. Mas a sua sociedade antiviolenta e o fato de que pelo menos metade do gênero dos primatas, como ele, não segue o padrão babuíno de hegemonia pela força demonstram o risco de se adotar modelos de pensamento único para explicar e agir sobre fenômenos tão complexos quanto a sociedade humana [...] E é daí que eles [muriquis] emitem seu apelo de paz aos primatas dominantes na Terra: nós, humanos. O muriqui 
talvez seja um parente mais remoto do homem do que o violento babuíno africano. Mas quem tem o privilégio de observá-lo na mata dificilmente resistirá à tentação de enxergar aí uma identidade possível. Um primo distante na escala da vida, porém próximo na utopia. Um arborícola que redime a solidariedade como hipótese de futuro (Globo Rural, ano 13, n.149, março 1998).

O que Fedigan (1986) chamou de "babuinização da vida primata", tomando um modelo humano e generalizando-o aos demais primatas, passa a ser invertido pelo marketing ecológico evocando uma "muriquização da vida humana". Argumenta-se que ambos os modelos primatas funcionam a partir de projeções da vida humana mas, ao contrário da realidade histórica sobreposta à construção da imagem dos babuínos [a Guerra Fria], o modelo hippie designado aos muriquis parece nunca ter sido efetivado enquanto condição precípua humana. Em vez disso, os "macacos hippies" surgem como uma substancialização animal alocada à subjetividade humana.

Note-se que o recurso utilizado para acentuar a especificidade dos muriquis deve afastá-los dos indícios biologicamente estabelecidos (padrões comportamentais, ecológicos e de organização social comuns entre os demais primatas) e aproximá-los através de linguagem culturalizante atribuída aos seres humanos. Grosso modo, os monos são especiais porque diferem dos demais primatas naquilo em que se assemelham a nós, humanos. Esta semelhança com o mundo dos humanos é sugerida como uma possibilidade, como um modelo utópico de como poderia ou deveria ser a sociedade humana ideal. Muito já foi dito - equivocadamente - acerca do fato de que os primatas contemporâneos detiveram-se em estágios proto-hominídeos da evolução. Contudo, não seria absurdo dizer que o mono-carvoeiro, a partir da cultura-linguagem utilizada para defini-lo pelos próprios primatólogos, apresente uma condição prototípica humana. Esta última jamais alcançada pelos humanos modernos, mas presente no estilo de vida pós-humano [ou a-moderno] destes macacos. É neste entroncamento que nos deparamos com a ideia de posse recíproca sustentada por Tarde (2003). Como podemos lidar com estes primatas, ao mesmo tempo por nós possuídos, mas que também nos possuem de forma a nos subjugar, relegando-nos a um desejo de transformação? Pois é aqui que se situa o argumento em torno do apelo à preservação do muriqui, manuseando seus possíveis devires. O que alguns argumentariam ser o limite da cadeia projecional - uma imagem humanizada, um discurso vulgarizado, uma Ciência profanada - em verdade é um recomeço a partir dos macacos hippies. Percebi que nesta referência circulante (Latour 2001), qualquer tentativa de evadir em direção à periferia nos reaproximava do centro. 


\section{O capital yuppie}

"Guilherme, você se incomodaria de filmar a festa?", perguntou-me o administrador da Estação. Aceitei de bom grado o pedido para registrar o evento comemorativo dos 20 anos da EBC.

Realizei meu trabalho de campo em um período que compreende o biênio 2003-2004, adotando a observação participante como prática principal para uma pesquisa em que as minhas perguntas aconteciam num permanente clima de informalidade gerenciado pelos pesquisadores (Sá 2005). Tive a oportunidade de estabelecer longas conversas com primatólogos, mateiros e funcionários que prestavam serviços àquele empreendimento científico. Entretanto, é provável que o evento narrado a seguir expresse melhor do que qualquer outro a magnitude desta rede de pesquisa e sua vascularização em relações diversas e inusitadas.

Durante alguns dias assisti à chegada de diversos pesquisadores ao alojamento. Gente conhecida da casa, outros, néofitos prontos para iniciar seu ciclo na reserva, conservacionistas vindos da capital, fotógrafos contratados por ONG's para cobrir o evento, repórteres do local, políticos, gente da família proprietária da fazenda e turistas. Turistas não de qualquer estirpe, como certa vez deixou claro o administrador da Estação em nota publicada no jornal local:

Mais uma vez os monos da Fazenda Montes Claros tiveram o prazer de receber em sua casa, a Estação Biológica de Caratinga, a visita de um grupo de turistas estrangeiros. Desta vez, o grupo era formado por pessoas importantes, de alto poder aquisitivo e que, vez por outra, fazem generosas doações às entidades do mundo inteiro [como o WWF]. Para se ter uma ideia da generosidade deste grupo, nos contou o dr. Russel Mittermeier, vice-presidente do WWF, que a empresa de um deles (do "velhinho de ouro"!) havia doado, no ano passado, US\$800.000,00 (oitocentos mil dólares!) ao Fundo, para o financiamento de projetos visando a conservação da natureza. É claro que esse dinheiro todo é descontado do imposto de renda deles, como existe a Lei Sarney aqui no Brasil. Em vez de entregarem seu dinheiro ao governo (que nem sempre sabe como usá-lo), o repassam a estas entidades. Pelo menos assim estarão certos de que seu dinheiro está sendo gasto para salvar milhares de espécies à beira do desaparecimento, como o nosso monocarvoeiro (A Semana Caratinguense, 25/12/19).

A importância da vinda destes visitantes era cada dia mais evidente e visível nas medidas tomadas na EBC: pintura das paredes externas do alojamento, fartos jantares financiados pelos estrangeiros, confecção de cami- 
setas e folders comemorativos, buffet especialmente contratado, elaboração de um painel com fotografias "históricas", apresentação de uma dupla de cantores sertanejos e até mesmo a construção de um palco a céu aberto de onde falariam alguns convidados ilustres. Vivia-se, naqueles dias, em que "eles" estavam entre nós, um regime de exceção.

Fui orientado a priorizar a filmagem destes convidados "VIP", mas meu amadorismo como cameraman acabou flagrando a presença dos funcionários e de suas famílias redistribuindo a lente que focalizava os discursos do prefeito da cidade de Ipanema, dos proprietários da fazenda, dos conservacionistas e as homenagens prestadas a personagens importantes na história da Estação.

Paralelamente ao cerimonial, ocorria uma trôpega incursão na mata à procura dos monos. Refiro-me ao grupo de contribuintes estrangeiros que, guiados por Mittermeier, vieram ao Brasil conhecer de perto no que investiam seu dinheiro. Acompanhados por Kira, Catarina, Jonas (primatólogos) e Jerônimo (mateiro), os turistas - entre idosos, jovens famílias e até mesmo um roteirista de um famoso seriado de animação norte-americano - deslocavam-se com dificuldade através da trilha que levava ao rincão onde se encontravam os animais. Flashes e comentários entusiasmados saudavam os macacos que assistiam a tudo aquilo duplamente bestializados. ${ }^{24} \mathrm{~A}$ atividade de avistamento dos monos havia sido estrategicamente planejada nos dias que antecediam a festa. Determinou-se o local exato através do acompanhamento diário do grupo de muriquis do Matão. Desta forma, todo trabalho havia sido feito com previdência e só restava torcer para que os monos não se deslocassem para alguma região de acesso mais difícil.

O mecenato científico atualizava-se nestas ocasiões em que convites eram feitos a pesquisadores renomados para falar sobre seus objetos de estudo - os macacos hippies — durante reuniões e jantares. A rede de produção científica se expande na medida em que relaciona os agentes mais diversos e quase inimagináveis. Por isso, sofria-se menos com um problema de contradição do que de contra dicção. Os efeitos das pronúncias obliteradas do discurso científico preservavam seu significado e simultaneamente rearticulavam os sons das palavras, pluralizando sua argumentação conforme a voz de seus oradores. Esta contra dicção assemelha-se a um double bind, ${ }^{25}$ como propôs Bateson: uma "trama de contextos e de mensagens que propõe contexto - mas que, como toda mensagem, só possui 'significado' em virtude do contexto" (Bateson 2000:275-6). Seu efeito está na presença de eventos aparentemente contrastivos, contraditórios, ou antagônicos - mas que não são confrontados - coexistindo em um mesmo sistema propositivo. Um bom exemplo situado diz respeito ao financiamento de projetos para a implantação 
de corredores ecológicos sob a justificativa de ampliar a área de uso dos primatas ilhados em determinadas regiões. O projeto persiste mesmo atestada a sua inviabilidade técnica, em função da sobreposição de barreiras naturais, como o curso de rios, que impediriam o trânsito dos animais. Entretanto, sua inaplicabilidade técnica não invalida o sentido da iniciativa a priori. Outro exemplo seria o tratamento privilegiado dado aos turistas-financiadores, concedendo-lhes acesso aos muriquis nos mais recônditos locais da mata, algo que é normativo e proibido, a fim de evitar qualquer tipo de interação que perturbe os primatas. "No creo en las brujas. Pero, que las hay, hay!". Mais do que a simples redução explicativa a um simplório capitalismo selvagem, turismo, conservação e pesquisa tornam-se constantes em uma intrincada equação na qual seus pesos variam constantemente.

\section{Tropeçando no elo perdido}

Relacionar muriquis a babuínos, ou relacioná-los a gorilas, chimpanzés ou mesmo aos humanos, não significa confrontar duas unidades monolíticas, pois agir desta forma seria assumir um mero jogo de trocas e comparações identitárias. Em contrapartida, se admitimos serem os muriquis o somatório de suas imagens/vidas potenciais - diversas - na medida em que expressam diferentes socialidades, bem como o outro na relação (babuínos, gorilas, chimpanzés, humanos etc.), conseguiremos, como resultado, permutações infinitas de visões, ideias, discursos e agenciamentos que talvez nos levem a enunciados mais abrangentes sobre o que pode ser um muriqui. Se "a diversidade e não a unidade estão no coração das coisas" (Tarde 2003:77), fluem em um mesmo corpo primata macacos hippies, com personalidade e constitutivos de exemplos a serem seguidos pelos humanos; seres perigosos; seres inofensivos; objetos de caça; seres bonitos; objetos de estudo; atrações turísticas; "gente vagarosa"; "não macacos"; duas sub-espécies hypoxanthus e arachnoides; duas espécies B. hypoxanthus (muriqui do norte) e $B$. arachnoides (muriqui do sul) etc.

O mesmo serviria para os babuínos: "machistas e agressivos"; "violentos"; modelo-padrão, "são como cachorros"; invasores e, ao mesmo tempo, "guias" e companhia. Muito além de se vincularem a uma única identidade, os babuínos são tudo isso e muito mais. Portanto, como nos lembra LéviStrauss (1989:174): "O conjunto constitui, então, uma espécie de aparelho conceitual que filtra a unidade através da multiplicidade, a multiplicidade através da unidade, a diversidade através da identidade e a identidade através da diversidade." 
Mesmo que belas vestimentas como a dos "macacos hippies" ou "gigantes gentis" ordinariamente pareçam hegemônicas, estas não devem anular a multiplicidade de imagens potencialmente viáveis mediante a aproximação intersubjetiva. Estas relações conformam elos reais num enredar de humanos e não humanos. São elos condicionáveis porque implicam justamente a instabilidade e mutabilidade das condições possíveis atribuídas a determinado actante e em nada lembram essencializações que apenas nos remetem à busca incessante por um fóssil incrustado em algum sambaqui sociológico.

Assim como na natureza das "balas perdidas", nada de problemático existe intrinsecamente nos chamados "elos perdidos". Em compensação, o imbroglio se inicia no local onde as/os encontramos.

Recebido em 10 de dezembro de 2009

Aprovado em 27 de maio de 2010

Guilherme José da Silva e Sá é professor do Departamento de Antropologia da Universidade de Brasília. E-mail: guilherme_jose_sa@yahoo.com.br

\section{Notas}

${ }^{1}$ Denominação abreviada para mono-carvoeiro ou muriqui.

${ }^{2}$ Durante minha pesquisa de campo, não encontrei qualquer relato contemporâneo atestando ser o muriqui uma caça localmente apreciada como a paca e o tatu. Diz-se que, em um passado remoto, os muriquis serviam de alimento, sobretudo aos indígenas, que apreciavam sua carne, tida como muito saborosa e que, paralelamente, mercadores retiravam os macacos da mata para servirem como animais de estimação.

${ }^{3}$ Reserva Privada do Patrimônio Natural Feliciano Miguel Abdala (MG).

${ }^{4}$ Duas pessoas se abraçam cruzando os braços em torno do corpo um do outro, ao mesmo tempo em que emitem o som (vocalização idêntica à dos monos): "Ô, hô, hô, hô, hôôôôôo...".

${ }^{5}$ Também conhecidos como "buriqui", "mburiqui", "barbudinho", "muriquina" e ainda, por corruptela, "mariquinha" ou "mariquina" (Von Ihering 1968). 
${ }^{6}$ Orientador de tese de Karen Strier.

7 Àquela época, diretor de pesquisas com primatas do World Wildlife Fund (WWF).

${ }^{8}$ Do Centro de Primatologia - RJ.

${ }^{9}$ Aqui me aproximo da crítica elaborada por Velho (2005a) e Velho (2005b).

${ }^{10}$ Tipo de locomoção que alterna os movimentos dos braços e da cauda, ou apenas os braços, como fazem os gibões asiáticos, pouco utilizando as pernas (patas traseiras).

${ }^{11}$ Espécie que também é encontrada em outras regiões, como a amazônica.

${ }^{12}$ Não há referência acerca de como os habitantes locais classificavam a quarta espécie de primata da região, o sagui-da-serra. Acredito que esta escassez de dados possa estar relacionada aos próprios hábitos da espécie: mais reclusos ao interior da mata, por isso mais difíceis de serem observados.

${ }^{13} \mathrm{O}$ antagonismo pouco construtivo dos pontos de vista de primatólogos e fazendeiros não deve ser generalizado, pois como observa Jane Goodall, ambos podem ser bastante úteis para a compreensão do comportamento dos primatas, desde que sejam tratados como formas de conhecimento complementares: "É difícil expressar adequadamente minha dívida para com meu falecido marido, Derek Bryceson, por sua ajuda, seu apoio e seus conselhos [...] Derek, com seu vasto conhecimento e compreensão da Tanzânia, ajudou-me a treinar a equipe de campo e a reorganizar a coleta de dados. Foram muitas as discussões que mantive com ele a respeito de aspectos intrigantes do comportamento dos chimpanzés. Seus comentários, proferidos a partir do ponto de vista de um fazendeiro, eram muitas vezes penetrantes, proporcionado-me novas percepções. Sua contribuição foi de fato muito grande; mesmo hoje, por ele ter sido tão amado e respeitado na Tanzânia, seu nome confere a mim, sua viúva, uma posição que eu nunca teria alcançado de outra forma" (Goodall 1991:271).

${ }^{14}$ Os monos e os barbados não entravam em suas plantações, apenas os macacos-prego.

${ }^{15}$ Já foi registrado o nascimento de gêmeos entre os muriquis da EBC.

${ }^{16}$ Mesmo quando adquirem uma relativa independência para se deslocarem, os filhotes ocasionalmente dependem de suas mães para passar de uma árvore a outra. Nesta situação, as mães encarregam-se de usar o próprio peso para aproximar os galhos das árvores diferentes ou formar com o corpo deitado e os braços estendidos um gesto característico denominado "fazer ponte", sobre a qual o júnior fará a travessia. 
${ }^{17}$ A mesma lógica adotada para explicar a equivalência no tamanho dos corpos entre os sexos rege o tamanho dos caninos de machos e fêmeas (iguais entre os muriquis), fato até então somente verificado em sociedades primatas monogâmicas.

${ }^{18}$ Teve influência inclusive entre sociobiólogos que estudavam questões relativas ao comportamento humano, dando origem a publicações polêmicas como Baker 1997.

${ }^{19}$ Mais sobre isso em Sperling 1991.

${ }^{20}$ Lógica endossada por Fouts (1998).

${ }^{21}$ Estas associações nominativas compostas com dimensões do "mundo humano" também podem ser encontradas entre outras classes de animais, como demonstra o caso das "moscas homossexuais" analisado por Houdart (2007).

${ }^{22}$ Ao caracterizar a relevância para as "pesquisas antropológicas", Mittermeier faz clara menção ao modelo universitário largamente adotado nos Estados Unidos da América, que concebe a formação profissional de um antropólogo em quatro campos ("four fields"), a saber, a antropologia cultural, a linguística antropológica, a arqueologia e a antropologia biológica. Este último campo englobaria, entre outros, o estudo da primatologia e da evolução humana.

${ }^{23}$ Uma iniciativa parecida já havia sido realizada durante as eleições municipais em 1988, no Rio de Janeiro. O grupo de humoristas "Casseta e Planeta Urgente!" lançou a candidatura do macaco Tião, um famoso chimpanzé que, na época, era o mascote do zoológico da cidade. Durante a apuração, ainda no sistema de cédulas de papel, foi verificado um grande número de votos para o "candidato não humano", todos considerados nulos.

${ }^{24}$ Bestializados: como bestas. Aqui, minha ideia não é me referir aos animais como "bestas" (relação animal-animal), mas descrevê-los em seu estado semelhante a humanos animalizados (relação animal-humano-animal), ou seja, retornando - via humanidade - a animais transformados.

${ }^{25}$ A hipótese do double bind foi formulada por Bateson a partir da observação de famílias de esquizofrênicos e contribuiu para sugerir que esta patologia mental poderia ser analisada como o resultado de uma disfunção do sistema de comunicação familiar. O double bind aparece, portanto, como uma contradição incontornável entre uma mensagem e o sistema que fornece as regras para sua interpretação. Bateson testará suas ideias posteriormente, no âmbito dos estudos de comunicação animal, especificamente entre os golfinhos. 


\section{Referências bibliográficas}

BAKER, Robin. 1997. Guerra de esperma. Rio de Janeiro: Record.

BATESON, Gregory. 2000. Steps to an ecology of mind. Chicago e Londres: The University of Chicago Press.

FEDIGAN, Linda. 1986. "The changing role of women in models of human evolution". Annual Review of Anthropology, XV:25-66.

FONSECA, Gustavo; MITTERMEIER, Russell. 2003. "Apresentação". In: M. T. Fonseca (ed.), A RPPN Feliciano Miguel Abdala e os 20 anos da Estação Biológica de Caratinga. Belo Horizonte: Conservation International do Brasil. pp. 02-04.

FOSSEY, Dian. 1983. Gorillas in the mist. Boston: Houghton Mifflin Company.

FOUTS, Roger. 1998. O parente mais próximo: o que os chimpanzés me ensinaram sobre quem somos. Rio de Janeiro: Editora Objetiva.

GOODALL, Jane. 1991. Uma janela para $a$ vida: 30 anos com os chimpanzés da Tanzânia. Rio de Janeiro: Jorge Zahar Editor.

HARAWAY, Donna. 1989. Primate visions. Gender, race and nature in the world of modern Science. Nova York: Routledge.

HOUDART, Sophie. 2007. La cour des miracles: ethnologie d'un laboratoire japonais. Paris: CNRS.

HRDY, Sarah B. 1981. The woman that never evolved. Cambridge: Harvard University Press.

INGOLD, Tim. 1994. "Humanity and animality". In: T. Ingold (ed.), Companion encyclopedia of anthropology. Londres: Routledge. pp. 3-13.

LATOUR, Bruno. 2000. "A well-articulated primatology: reflections of a fellow-traveller". In: S. C. Strum e L. Fedigan (eds.), Primate encounters: models of science, gender, and society. Chicago: The University of Chicago Press. pp. 358-381.

LATOUR, Bruno. 2001. A esperança de Pandora: ensaios sobre a realidade dos estudos científicos. Bauru: EDUSC.

LÉVI-STRAUSS, Claude. 1989. O pensamento selvagem. Campinas: Papirus Editora.

MILTON, Katherine. 1984. "Habitat, diet, and activity patterns of free-ranging woolly spider monkeys (Brachyteles archnoides E. Geoffroy 1806)". International Journal of Primatology, $\mathrm{V}: 491-514$

MILTON, Katherine. 1985a. "Multimale mating and absence of canine tooth dimorphism in woolly spider monkeys (Brachyteles arachnoides)". American Journal of Physical Anthropology, LXVIII:519-523.

MILTON, Katherine. 1985b. "Mating patterns of woolly spider monkeys, Brachyteles arachnoides: implications for female choice". Behavioral Ecology and Sociobiology, XVII:53-59.

PICQ, Pascal. 2002. Le singe est-il le frère de l'homme?. Paris: Éditions Le Pommier.

SÁ, Guilherme. 2005. "Meus macacos são vocês. Um antropólogo seguindo primatólogos em campo". Revista Anthropológicas, XVI(2):41-66.

SCHIENBINGER, Londa. 2001. O feminismo mudou a ciência?. Bauru: EDUSC.

SPERLING, Susan. 1991. "Baboons with briefcases vs. Langurs in lipstick: feminism and functionalism in primate studies". In: M. Di Leonardo 
(org.), Gender at the crossroads of knowledge. Berkeley: University of California. pp. 204-234.

STRIER, Karen B. 1992. Faces in the forest: the endangered muriqui monkeys of Brazil. Nova York: Oxford University Press.

TARDE, Gabriel. 2003. Monadologia e sociologia. Petrópolis: Editora Vozes.

VEADO, Eduardo M. A. 2003. "Biodiversidade da RPPN Feliciano Miguel Abdala". In: M. T. Fonseca (ed.), A RPPN Feliciano Miguel Abdala e os 20 anos da Estação Biológica de Caratinga. Belo Horizonte: Conservation International do Brasil. pp. 10-17.

VELHO, Otavio G. 2005a. "Comentários sobre um texto de Bruno Latour". Mana.Estudos de Antropologia Social, 11(1):297-309.

. 2005b. "Trajetórias e diversidade: um caso brasileiro". Texto apresentado na VI RAM, Montevideo. Mimeo.

VIVEIROS DE CASTRO, Eduardo B. 2002. A inconstância da alma selvagem. São Paulo: Cosac \& Naify.

IHERING, Rudolf Von. 1968. Dicionário dos animais do Brasil. São Paulo: Editora Universidade de Brasília.

WRANGHAM, Richard. 1979. "On the evolution of ape social systems". Social Science Information, XVIII:335386.

WRANGHAM, Richard. 1980. "An ecological model of female-bounded primate groups". Behavior, LXXV:262-299. 


\section{Resumo}

A partir de pesquisa etnográfica junto a um grupo de primatólogos atuando em um fragmento da Mata Atlântica mineira, proponho tratar de algumas questões caras à antropologia da ciência, em especial daquela que da perspectiva etnológica se interessa pelas relações entre humanos e não humanos e pelas dinâmicas cosmológicas de atuação deste coletivo. Neste trabalho dedico-me à analise das formas de construção da imagem e agenciamento dos primatas estudados [conhecidos como "muriquis" ou "mono-carvoeiros"] que permeiam o discurso-cultura dos pesquisadores. Procura-se apresentar este coletivo de humanos e não humanos mapeando suas relações e variações dispostas na circulação de imagens, comportamentos e performances transespecíficas.

Palavras-chave Antropologia da Ciência, Controvérsias, Primatologia, Muriquis, Narrativas transespecíficas

\section{Abstract}

Based on ethnographic fieldwork with a team of primatologists working in a small area of Brazilian Atlantic Forest, this paper engages with some of the classical issues in the anthropology of science, especially the ethnological interest in the relations between humans and nonhumans and the cosmological dynamics that shape this collective. The paper focuses on how the image and agency of the primates is constructed (woolly-spider monkeys known as 'muriquis' or 'monocarvoeiros') and also analyzes their appropriation by primatological discourseculture. As well as tracing the relations forming this collective of humans and non-humans, the text maps the variations composed of images, behaviours and transpecific performances.

Key words Anthropology of Science, Controversies, Primatology, Woolly spider monkey, Transpecific narratives 